\title{
The Dynamic Effect of Unemployment Rate on Per Capita Real GDP in Iran
}

\author{
Ali A. Naji Meidani \\ Faculty of Economic and Administrative Sciences, Ferdowsi University of Mashhad \\ PO box 91779- 48951, Park Square, Ferdowsi University of Mashhad, Iran \\ E-mail: naji@um.ac.ir \\ Maryam Zabihi (Corresponding author) \\ Faculty of Economic and Administrative Sciences, Ferdowsi University of Mashhad \\ PO box 91779- 48951, Park Square, Ferdowsi University of Mashhad, Iran \\ E-mail: m.zabihi20@gmail.com
}

Received: February 25, 2011

Accepted: April 21, 2011

doi:10.5539/ijef.v3n5p170

\begin{abstract}
Unemployment is an important issue in developing economies. High unemployment means that labor resources are not being used efficiently. In this research, the dynamic effects of unemployment rate on per capita real GDP in Iran are investigated during the period 1971 to 2006 using an Auto-Regressive Distributed Lag (ARDL). Also in this model, the physical capital, the consumer price index and the ratio of government expenditure to GDP as control variables have been considered. The findings show that the unemployment rate has a significant and negative effect on per capita real GDP in long-run and short-run. The value of error correction coefficient is equal to -0.48 implying that around $95 \%$ of the per capita real GDP adjustment occurs after two years.
\end{abstract}

Keywords: Unemployment rate, Per capita real GDP, Auto-Regressive Distributed Lag (ARDL), Error correction mechanism

\section{Introduction}

Unemployment is an important issue in developing economies. High unemployment means that labor resources are not being used efficiently. Hence, full employment should be a major macroeconomic goal of any government because it maximizes output.

The bivariate system of output and unemployment rate is one of the most commonly studied in the VAR tradition to analyze the propagation and the persistence of shocks in the real economy and the transmission mechanism between product and labor market.

The Islamic Republic of Iran is the second-largest country in the Middle-east. With GDP per head standing at USD 3610 in 2007, the country is classified by the World Bank as a lower-middle-income country.

Iran's economy has experienced robust growth, with real GDP averaging 5.6\% over the past five years. Strong performance was primarily bolstered by high oil prices and the fiscal stimulants. These factors will continue to support Iran's economy in our forecast period. On the demand side, private consumption and investment will largely support the growth. However, private consumption will be hampered by skyrocketing inflation. Investment will remain strong, but is exposed to significant downside risks. The fear of military attack has eased after the release of the US intelligence report concluding that Iran eased developing nuclear weapons in 2003(Chen, 2008).

Some observers contend that the unemployment rate is higher than figures reported by the Iranian government. The unemployment rate remains high, reaching an estimated $11.8 \%$ in 2008 . At least one-fifth of Iranians lived below the poverty line in 2002. Iran has a young population and each year, about 750,000 Iranians enter the labor market for the first time, placing pressure on the government to generate new jobs. The emigration of young skilled and educated people continues to pose a problem for Iran. The IMF reported that Iran has the highest "brain drain" rate in the world (Shayerah, 2010)

The purpose of this paper is to offer a thorough statistical investigation of the joint dynamics of output and unemployment rate. 
It is essential to look at unemployment rate and per capita real GDP trends in Iran for the period ranging from 1971 to 2006(Figure $1 \& 2$ ).

The paper is organized in V Sections. Section II summarizes some recent literature on the subject. Section III explains data and mathematical model employed to capture the influence of macroeconomic factors on per capita real GDP. Section IV incorporates the empirical results of bounds testing procedure proposed by Pesaran. Section V concludes the study and discusses some implications for the current debate about the impacts of macroeconomic factors on per capita real GDP in general.

\section{Review of literature}

Villaverde and Maza (2009) analyze Okun's law for the Spanish regions over the period 1980-2004. They found that an inverse relationship between unemployment and output holds for most of the regions and for the whole country. However, the quantitative values of Okun's coefficients are quite different, a result that is partially explained by regional disparities in productivity growth. These differences imply that, when it comes to policy issues, conventional aggregate demand/supply management policies should be combined with region-specific policies.

Zaleha et al. (2007) examine relationship between output and unemployment in the Malaysian economy. They found that the negative relationship between output and unemployment is present. They also found two-way causality between unemployment and output growth in Malaysia.

Christopoulos (2004) investigates the relationship between output and unemployment in Greece at a regional level through the implementation of Okun's law. Current practice is primarily restricted to the national level, and thus ignores the regional dimension of this relationship. He uses modern unit root test and co-integration techniques based on panel data settings. The empirical results reveal that Okun's law can be confirmed for six out of the 13 regions we examine.

Perman and Tavera (2004) examine for the presence of convergence of the Okun's Law coefficient (OLC) among several alternative groupings of European economies. The empirical strategy adopted is based on the evaluation of the time path of rolling regression estimates of the OLC for European countries. They then use a testing procedure suggested by Evans (1996) to investigate the convergence, or non-convergence, of the OLC in several groups of European countries by examining how the cross-country variance of the OLC evolves over time in these groups. A hypothesis of medium-term convergence of the OLC is rejected for most of the European country groups examined.

Gil-Alana (2002) investigates the presence of structural breaks in the US output and unemployment rate by means of using fractionally integrated techniques. The results indicate that, for unemployment, the inclusion of breaks does not affect to the degree of integration of the series, while for the GNP, they observe a reduction in its order of integration of about 0.25 when a break due to the oil price crisis is taken into account.

Dornbusch et.al (2001) argue that forgone output is the major cost of unemployment, and if the loss is very high it could lead to recession.

Freeman (2001) uses new developments in trend/cycle decomposition to test Okun's Law for a panel of ten industrial countries, finding that Okun's original estimate for the U.S. of three points of real GDP growth for each one percent reduction in the unemployment rate now averages just under two points of real GDP growth for the sample countries. Also, he finds that omission of capital and labor inputs may have biased previous estimates.

As Romer (2001) reports, there is a well-established stylized fact about the fluctuations in the US economy - that the employment rate is pro-cyclical and the unemployment rate counter-cyclical. During all the recessions in the 1947-1999 period he finds that the employment fell $3.6 \%$ on the average, and also that the rate shrank during each of the periods.

Balmaseda et al. (2000) use data for a sample of 16 OECD countries from 1950 to 1989 in order to assess the effect of aggregate demand, productivity, and labor supply shocks on the real output, real wages and the unemployment rate. They found that unemployment rate fluctuations are dominated by aggregate demand shocks in the short-run.

Lee (2000) evaluates the robustness of the Okun relationship based on postwar data for 16 OECD countries. He uses two different approaches, the first-difference and the "gap" model. He finds statistically significant Okun's coefficients for almost all countries, but some differences among the countries. Some countries are characterized by low absolute values of the coefficient, which he attributes mainly to rigidities in the labor market.

Weber (1995) uses four different methods to extract the cyclical components of the output and the unemployment. He uses the cyclical components to derive estimates of Okun's coefficient for the US economy during the period 1948 to 1988 . He found that the values of the coefficient range from -0.22 to -0.31 , thus contradicting the claim that Okun's coefficient is rather stable around the -0.3 value. 
Prachowny (1993) found that changes in output will result in changes in efficiency of production. Other important determinants of output include the amount of time worked and exploitation of facility space.

Watts and Mitchell (1991) supported Okun's law. According to their study, the long-term relationship between unemployment and capacity utilization is not stable. Factors such as increasing labor resource utilization weaken the estimations of Okun's law.

Evans (1989) uses data for the US economy from 1950 to 1989 in order to assess the relationship between the GDP growth and the unemployment rate. He finds a "substantial feedback" between the two variables, supported by the contemporaneous correlation between them. Using a non-restricted bivariate VAR he shows that there is a long-run relationship between the GDP growth and unemployment at about 0.30, in line with Okun's findings.

Hamada and Kurosaka (1984) study the question whether the celebrated "Okun's law", a relation between excess capacity and unemployment, applies to the postwar Japanese economy. The coefficient that measures the responsiveness of the output gap to the unemployment rate is very large, reaching 28 . This large coefficient can be attributed to the elastic response in the female participation ratio, to flexible working hours, to the slow adjustment in employment, and to changes in industrial structures.

Although the empirical study of Okun's law has indeed blossomed since the publication of Prachowny's paper (1993), most of it only deals with data at national level. Fortunately, in the last few years some studies have tried to overcome this shortcoming, thus introducing a regional dimension in the analysis of the relationship between output and unemployment.

\section{Method}

There are several methods available to test for the existence of the long-run equilibrium relationship among time-series variables. The most widely used methods include Engle and Granger (1987) test, fully modified OLS procedure of Phillips and Hansen's (1990), maximum likelihood based Johansen $(1988,1991)$ and Johansen-Juselius (1990) tests. These methods require that the variables in the system are integrated of order one I(1). In addition, these methods suffer from low power and do not have good small sample properties. Due to these problems, a newly developed autoregressive distributed lag (ARDL) approach to co-integration has become popular in recent years. This study employs autoregressive distributed lag approach (ARDL) to co-integration following the methodology proposed by Pesaran and Shin (1999). This methodology is chosen as it has certain advantages on other cointegration procedures. First, the series used do not have to be I(1) (Pesaran \& Pesaran, 1997). Second, even with small samples more efficient cointegration relationships can be determined (Ghatak \& Siddiki, 2001). Finally, the ARDL approach overcomes the problems resulting from non-stationary time series data leading to spurious regression coefficient that are biased towards zero (Stock \& Watson, 1993).

First of all data has been tested for unit root. This testing is necessary to avoid the possibility of spurious regression as Ouattara (2004) reports that bounds test is based on the assumption that the variables are $\mathrm{I}(0)$ or $\mathrm{I}(1)$ so in the presence of I(2) variables the computed F-statistics provided by Pesaran et al. (2001) becomes invalid. Similarly other diagnostic tests are applied to detect serial correlation, heteroscedasticity , conflict to normality.

If data is found $\mathrm{I}(0)$ or I(1) the ARDL approach to co-integration is applied which consists of three stages. In the first step the existence of a long-run relationship between the variables is established by testing for the significance of lagged variables in an error correction mechanism regression. Then the first lags of the levels of each variable are added to the equation to create the error correction mechanism equation and a variable addition test is performed by computing an F-test on the significance of all the lagged variables.

The second stage is to estimate the ARDL form of equation where the optimal lag length is chosen according to one of the standard criteria such as the Akaike Information or Schwartz Bayesian. Then the restricted version of the equation is solved for the long-run solution. An ARDL representation of above equation is as below:

$$
\begin{aligned}
& \operatorname{LCGDP}_{t}=\alpha_{0}+\sum_{i=1}^{p} \delta_{1} \text { LCGDP }_{t-i}+\sum_{i=0}^{q_{1}} \delta_{2} \text { LUNEMP }_{t-i}+\sum_{i=0}^{q_{2}} \delta_{3} \text { LCPI }_{t-i} \\
& +\sum_{i=0}^{q_{3}} \delta_{4} L K_{t-i}+\sum_{i=0}^{q_{4}} \delta_{5} L G R_{t-i}+\varepsilon_{t}
\end{aligned}
$$

Where

CGDP $=$ Per Capita Real GDP

UNEMP $=$ Unemployment Rate

$\mathrm{CPI}=$ Consumer Price Index 
GR $=$ Ratio of Government Expenditure to GDP

$\mathrm{K}=$ Physical Capital

The third stage entails the estimation of the error correction equation using the differences of the variables and the lagged long-run solution, and determines the speed of adjustment of returns to equilibrium. A general error correction representation of equation is given below:

$$
\begin{aligned}
& \Delta L C G D P_{t}=\mu+\sum_{i=1}^{p} \phi_{i} \Delta L C G D P_{t-i}+\sum_{j=1}^{q} \varpi_{j} \Delta L U N E M P_{t-j}+\sum_{l=1}^{q} \varphi_{l} \Delta L C P I_{t-l} \\
& +\sum_{m=1}^{q} \gamma_{m} \Delta L G R_{t-m}+\sum_{p=1}^{q} \eta_{p} \Delta L K_{t-p}+\vartheta E C M_{t-1}+\varepsilon_{t}
\end{aligned}
$$

Here $\phi, \varpi, \varphi, \gamma$, and $\eta$ are the short-run dynamic coefficients of the model's convergence to equilibrium and $\vartheta$ is the speed of adjustment. The F-test is used for testing the existence of long-run relationship. When long-run relationship exist, F-test indicates which variable should be normalized. The null hypothesis for no co-integration among variables is $H_{0}: \delta_{1}=\delta_{2}=\delta_{3}=\delta_{4}=\delta_{5}=0$ against the alternative hypothesis $H_{1}: \delta_{1} \neq \delta_{2} \neq \delta_{3} \neq \delta_{4} \neq \delta_{5} \neq 0$. The F-test has a non-standard distribution which depends on (i) whether variables included in the model are I(0) or I(1), (ii) the number of regressors, and (iii) whether the model contains an intercept and/or a trend. Given a relatively small samples size, the critical values used are as reported by Narayan(2004) which based on small sample size between 30 and 80 . The test involves asymptotic critical value bounds, depending whether the variables are I(0) or I(1) or mixture of both. Two sets of critical values are generated which one set refers to the $\mathrm{I}(1)$ series and the other for the $\mathrm{I}(0)$ series. Critical values for the $\mathrm{I}(1)$ series are referred to as upper bound critical values, while the critical values for $\mathrm{I}(0)$ series are referred to as the lower bound critical values.

If the F-test statistic exceeds their respective upper critical values, we can conclude that there is evidence of a long-run relationship between the variables regardless of the order of integration of the variables. If the test statistic is below the upper critical value, we cannot reject the null hypothesis of no co-integration and if it lies between the bounds, a conclusive inference cannot be made without knowing the order of integration of the underlying regressors.

To complement this study it is important to investigate whether the above long run relationship we found are stable for the entire period of study. In other words, we have to test for parameter stability. The methodology used here is based on the cumulative sum (CUSUM) and the cumulative sum of squares (CUSUMSQ) tests proposed by Brown et al. (1975). Unlike the Chow test, that requires break point(s) to be specified, the CUSUM tests can be used even if we do not know the structural break point. The CUSUM test uses the cumulative sum of recursive residuals based on the first $\mathrm{n}$ observations and is updated recursively and plotted against break point. The CUSUMSQ makes use of the squared recursive residuals and follows the same procedure. If the plot of the CUSUM and CUSUMSQ stays within the 5 percent critical bound the null hypothesis that all coefficients are stable cannot be rejected. If however, either of the parallel lines are crossed then the null hypothesis (of parameter stability) is rejected at the 5 percent significance level.

\section{Results}

Table 1 reports the results of unit root test applied to determine the order of integration among time series data. ADF Test has been used at level and first difference under assumption of constant and trend.

Results clearly indicate that the index series except for unemployment rate are not stationary at level but the first differences of the logarithmic transformations of the series are stationary. Therefore, it can be safely said that series are integrated of order one I(1). As suggested by Pesaran and Shin(1999) and Narayan(2004), since the observations are annual, we choose 2 as the maximum order of lags in the ARDL and estimate for the period of 1971-2006. In fact, we also used the Schwarz-Bayesian criteria (SBC) to determine the optimal number of lags to be included in the conditional ECM(error correction model), whilst ensuring there was no evidence of serial correlation, as emphasized by Pesaran et al.(2001).

Table 2 indicates that macroeconomic variables significantly explain per capita real GDP. The value of R-Bar-Squared is 0.95 which indicates a high degree of correlation among variables.

The F-test is used for testing the existence of long-run relationship. The calculated F-statistic $(\mathrm{F}$-statistic $=4.856)$ is higher than the upper bound critical value at 5 per cent level of significance (4.049), using restricted intercept and no trend. But the F-statistic is only higher than the upper bound critical value at 10 per cent level of significance (4.084), using restricted intercept and trend. This implies that the null hypothesis of no co-integration cannot be accepted at 5 per cent and 10 per cent level and therefore, there is a co-integration relationship among the variables. 
After analyzing the bound test for co-integration, next step is to estimate the coefficient of the long-run relationships.

Table 3 displays the results long-run coefficients under ARDL approach. Results reveal that unemployment rate, the physical capital, the consumer price index and the ratio of government expenditure to GDP have significant long-run effect on per capita real GDP.

The unemployment rate and the consumer price index are significantly negatively related with per capita real GDP which are logical as increase in these variables leads to increase in per capita real GDP. The physical capital and the ratio of government expenditure to GDP are significantly positively related with per capita real GDP.

Error Correction Representation of above long-run relationship is reported in Table 4 which captures the short-run dynamics of relationship among macroeconomic variables and per capita real GDP. The error correction model based upon ARDL approach establishes that changes in unemployment rate, the physical capital, the consumer price index and the ratio of government expenditure to GDP have significant short-run effect.

According to results short-run elasticities of unemployment rate, the consumer price index, the ratio of government expenditure to GDP and the physical capital are $-0.16,-0.38,0.11$ and 0.12 respectively. It is worth mentioning that these elasticities are much lower than long run elasticities. ECM(-1) is one period lag value of error terms that are obtained from the long-run relationship. The coefficient of ECM(-1) indicates how much of the disequilibrium in the short-run will be fixed (eliminated) in the long-run.

As expected, the error correction variable $\operatorname{ECM}(-1)$ has been found negative and also statistically significant. The Coefficient of the ECM term suggests that adjustment process is quite fast and $47 \%$ of the previous year's disequilibrium in per capita real GDP from its equilibrium path will be corrected in the current year.

Finally, CUSUM and CUSUMSQ plots are drawn to check the stability of short-run and long-run coefficients in the ARDL error correction model. Figure $3 \& 4$ show that both CUSUM and CUSUMSQ are within the critical bounds of $5 \%$ so it indicates that the model is structurally stable.

\section{Discussion and conclusion}

This study examines the relationship between the unemployment rate and per capita real GDP for the period 1971 to 2006 by using autoregressive distributed lag approach based on bounds testing procedure proposed by Pesaran and Shin (2001).

Unit root test clearly indicate that the index series except for unemployment rate are not stationary at level but the first differences of the logarithmic transformations of the series are stationary.

Results of ARDL long-run coefficients reveal that unemployment rate, the physical capital, the consumer price index and the ratio of government expenditure to GDP are statistically significant in determining per capita real GDP in the long-run. The error correction model based upon ARDL approach indicates that changes in the above-mentioned variables are statistically significant in the short-run.

Based on the results of short-run and long-run, the unemployment rate and the consumer price index are negatively related with per capita real GDP, while the physical capital and the ratio of government expenditure to GDP are positively related with per capita real GDP.

The error correction variable ECM(-1) has been found negative and statistically significant. The Coefficient of the ECM term suggests that adjustment process is quite fast and $47 \%$ of the previous year's disequilibrium in per capita real GDP from its equilibrium path will be corrected in the current year. CUSUM and CUSUMSQ plots are drawn to check the stability of short run and long run coefficients in the ARDL error correction model and. CUSUM and CUSUMSQ are within the critical bounds of 5\% that indicates that the model is structurally stable.

\section{References}

Balmaseda, M., Dolado, J. and López-Salido, J.D. (2000). The dynamic effects of shocks to labour markets: evidence from OECD countries, Oxford Economic Papers, 52, 3-23. doi:10.1093/oep/52.1.3, http://dx.doi.org/10.1093/oep/52.1.3

Brown, R.L., Durbin, J. and Evans, J.M. (1975). Techniques for Testing the Consistency of Regression Relations Over Time, Journal of the Royal Statistical Society, 37, 149-92.

Chen, D.(2008). Country report, Economic Research Department.

Christopoulos, D. (2004) The relationship between output and unemployment: Evidence from Greek regions, Papers in Regional Science, 83, 611-620. doi:10.1111/j.1435-5597.2004.tb01928.x, http://dx.doi.org/10.1111/j.1435-5597.2004.tb01928.x 
Dornbusch, R., Fosher, S. and Startz, R. (2001). Macroeconomics, McGraw-Hill.

Engle, R. F. and Granger, C. W. J.(1987). Co-integration and Error Correction: Representation, Estimation and

Testing, Econometrica, 55, 251-276. doi:10.2307/1913236, http://dx.doi.org/10.2307/1913236

Evans, M.D.R. (1989). Immigrant Entrepreneurship: Effects of Ethnic Market Size and Isolated Labor Pool, American Sociological Review, 54, 950-962. doi:10.2307/2095717, http://dx.doi.org/10.2307/2095717

Freeman, D.G. (2001). Panel Tests of Okun's Law for Ten Industrial Countries, Economic Inquiry, 39, 511-513. doi:10.1093/ei/39.4.511, http://dx.doi.org/10.1093/ei/39.4.511

Ghatak, S. and Siddiki, J. (2001). The use of ARDL approach in estimating virtual exchange rates in India, Journal of Applied Statistics, 28, 573-583. doi:10.1080/02664760120047906, http://dx.doi.org/10.1080/02664760120047906

Gil-Alana, L. (2002). Structural breaks and fractional integration in the US output and unemployment rate, Economics $\quad$ Letters, 77, 79-84. doi:10.1016/S0165-1765(02)00106-4, http://dx.doi.org/10.1016/S0165-1765(02)00106-4

Hamada, K. and Kurosaka, Y. (1984). The relationship between production and unemployment in Japan: Okun's law in comparative perspective, European Economic Review, 25(1), 71-94. doi:10.1016/0014-2921(84)90073-4, http://dx.doi.org/10.1016/0014-2921(84)90073-4

Johansen, S. (1988). Statistical analysis of co-integration vectors, Journal of Economic Dynamics and Control, 12, 231-254. doi:10.1016/0165-1889(88)90041-3, http://dx.doi.org/10.1016/0165-1889(88)90041-3

Johansen, S. and Juselius, K.(1990). Maximum likelihood estimation and inference on co-integration with applications to the demand for money, Oxford Bulletin of Economics and Statistics, 51, 169-210

Johansen, S.(1991). Estimation and Hypothesis Testing of Co-integration Vectors in Gaussian Vector Autoregressive Models, Econometrica, 59(6),1551-1580. doi:10.2307/2938278, http://dx.doi.org/10.2307/2938278

Lee, J. (2000). The Robustness of Okun's Law: Evidence from OECD Countries, Journal of Macroeconomics, 22, 331-56. doi:10.1016/S0164-0704(00)00135-X, http://dx.doi.org/10.1016/S0164-0704(00)00135-X

Narayan, P.K. (2004). Reformulating critical values for the bounds F-statistics approach to co-integration: an application to the tourism demand model for Fiji, Department of Economics Discussion Papers, No.2,pp.4.

Ouattara, B. (2004a). The Impact of Project Aid and Program Aid on Domestic Savings: A Case Study of Côte d'Ivoire, Centre for the Study of African Economies Conference on Growth, Poverty Reduction and Human Development in Africa.

Ouattara, B. (2004b). Foreign Aid and Fiscal Policy in Senegal, Mimeo University of Manchester.

Perman, R. and Tavera, C. (2004) .Testing for convergence of the Okun's law coefficient in Europe, Discussion Papers in Economics, 04-12, University of Stractchclyde.

Pesaran, M. H. and Pesaran, B. (1997). Working with Microsoft 4.0, Camfit data Ltd, Cambridge.

Pesaran and Shin (1999). An autoregressive distributed lag modeling approach to co-integration analysis. DAE Working papers, No.9514.

Pesaran, M., Shin, Y. and Richard, J.S. (2001). Bounds testing approaches to the analysis of level relationships, Journal of Applied Econometrics, 16(3), 289-326. doi:10.1002/jae.616, http://dx.doi.org/10.1002/jae.616

Phillips, P.C.B. and Hansen, B.E. (1990). Statistical Inference in Instrumental Variables Regression with I(1) Processes, Review of Economic Studies, 57, 99-125. doi:10.2307/2297545, http://dx.doi.org/10.2307/2297545

Prachowny, M.F.J. (1993). Okun's Law: Theoretical Foundations and Revisited Estimates, Review of Economics and Statistics, 75, 331-335. doi:10.2307/2109440, http://dx.doi.org/10.2307/2109440

Romer, D. (2001). Advanced Macroeconomics, 2nd edition, New York: McGraw-Hill/Irwin.

Shayerah, I. (2010). Iran's Economic Conditions: U.S. Policy Issues, Congressional Research Service.

Stock, J. H. and Watson, M. (1993). A simple estimator of co-integrating vectors in higher order integrated systems. Econometrica, 61, 783-820. doi:10.2307/2951763, http://dx.doi.org/10.2307/2951763 
Villaverde, J. and Maza, A. (2009). The robustness of Okun's Law in Spain, 1980-2004: Regional evidence, Journal of Policy Modeling, 31(2), 289-297. doi:10.1016/j.jpolmod.2008.09.003, http://dx.doi.org/10.1016/j.jpolmod.2008.09.003

Watts, M. and Mitchell, W. (1991). Alleged Instability of the Okun's Law Relationship in Australia, Applied Economics, 23, 1829-1838. doi:10.1080/00036849100000172, http://dx.doi.org/10.1080/00036849100000172

Weber, C.E. (1995). Cyclical Output, Cyclical Unemployment, and Okun's Coefficient: A New Approach. Journal of Applied Econometrics, 10, 433-445. doi:10.1002/jae.3950100407, http://dx.doi.org/10.1002/jae.3950100407

Zaleha, M., Norashidah, M. and Judhiana, A. (2007) The Relationship between Output and Unemployment in Malaysia: Does Okun's Law exist?, Unemployment in Malaysia: Does Okun's Law exist?, International Journal of Economics and Management, 1(3),337-344.

Table1. Unit Root Analysis

\begin{tabular}{c|c|c|c|c}
\hline \multicolumn{2}{c|}{ intercept but not a trend } & \multicolumn{2}{c}{ intercept and a linear trend } \\
\hline Variable & ADF-Level & ADF-Ist Diff & ADF-Level & ADF-Ist Diff \\
\hline LCGDP & -1.9218 & -3.0312 & -2.6333 & -5.0503 \\
\hline LUNEMP & -3.7108 & Static & -3.0621 & Static \\
\hline LCPI & -0.17775 & -3.7532 & -2.5420 & -3.7091 \\
\hline LK & -1.2116 & -5.5682 & -1.6690 & -6.3067 \\
\hline LGR & -1.7200 & -4.3623 & -1.1009 & -5.1147 \\
\hline 5\% Critic Value & -2.9665 & -2.9706 & -3.5731 & -3.5796 \\
\hline
\end{tabular}

Table 2. ARDL $(1,1,0,0,1)$ selected based on SBC

\begin{tabular}{|c|c|c|c|c|}
\hline T Ratio & S. Error & Coefficient & Regressor & Prob. \\
\hline $\operatorname{LCGDP}(-1)$ & 0.42362 & 0.11413 & 3.7117 & 0.000 \\
\hline LCPI & -0.38217 & 0.12194 & -3.1342 & 0.004 \\
\hline LCPI(-1) & 0.081234 & 0.019809 & 4.1009 & 0.000 \\
\hline LUNEMP & -0.16309 & 0.050184 & -3.2498 & 0.003 \\
\hline LGR & 0.11388 & 0.039594 & 2.8763 & 0.008 \\
\hline LK & 0.11761 & 0.054988 & 2.1389 & 0.042 \\
\hline LK(-1) & 0.043308 & 0.059211 & 0.73142 & 0.471 \\
\hline \multirow[t]{4}{*}{$\mathrm{C}$} & 2.6963 & 0.57360 & 4.7008 & 0.000 \\
\hline & $\begin{array}{c}R^{2}=0.96512 \\
\text { D. } \mathrm{W}=1.86\end{array}$ & $\overline{R^{2}}=0.95396$ & & \\
\hline & $X_{S C}^{2}(1)=0.047[0.82]$ & $X_{F}^{4}(1)=0.44[0.50]$ & & \\
\hline & $X_{N}^{2}(2)=0.607[0.73]$ & $X_{H}^{2}(1)=1.44[0.23]$ & & \\
\hline
\end{tabular}

Table 3. Estimated Long Run Coefficients for selected ARDL Model

\begin{tabular}{|c|c|c|c|c|}
\hline Regressor & Coefficient & S. Error & T Ratio & Prob. \\
\hline LCPI & -0.42087 & 0.12401 & -3.3939 & 0.000 \\
\hline LUNEMP & -0.34235 & 0.085850 & -3.9878 & 0.001 \\
\hline LGR & 0.23906 & 0.069639 & 3.4328 & 0.002 \\
\hline LK & 0.25983 & 0.11891 & 2.1851 & 0.031 \\
\hline $\mathrm{C}$ & 5.6600 & 1.5451 & 3.6633 & 0.001 \\
\hline
\end{tabular}

Table 4. Error Correction Representation for the Selected ARDL Model

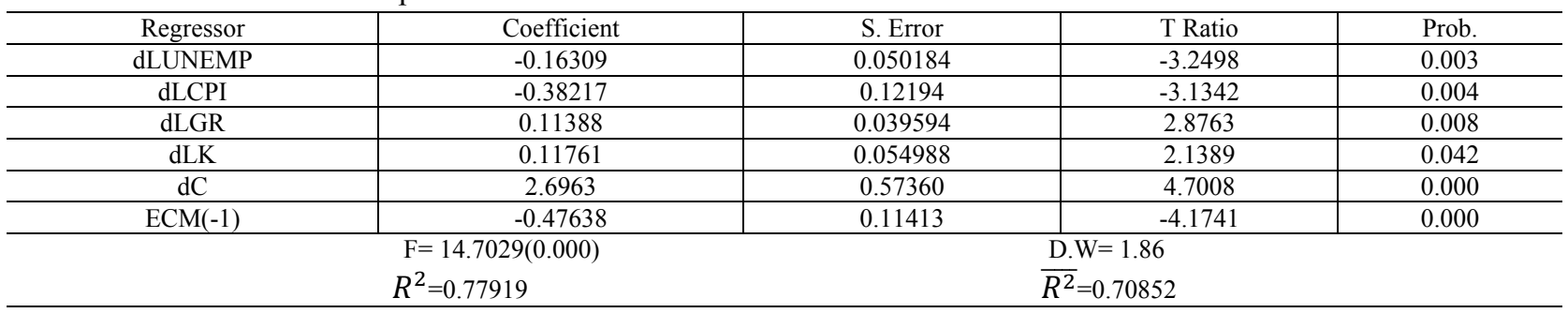




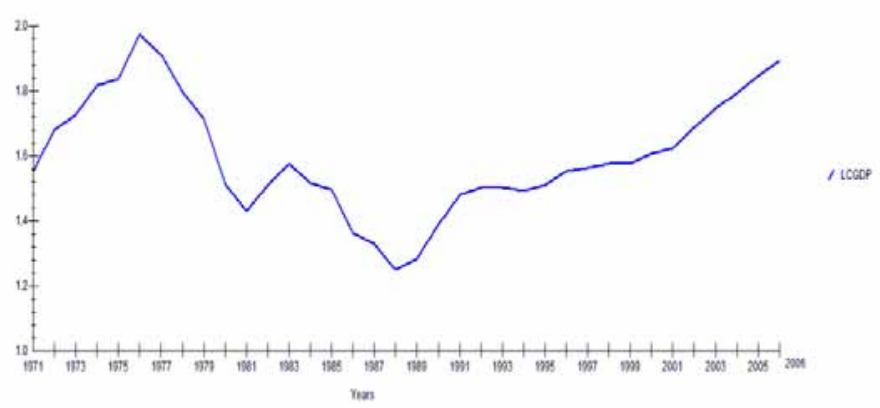

Figure 1. Per Capita Real GDP Trends in Iran

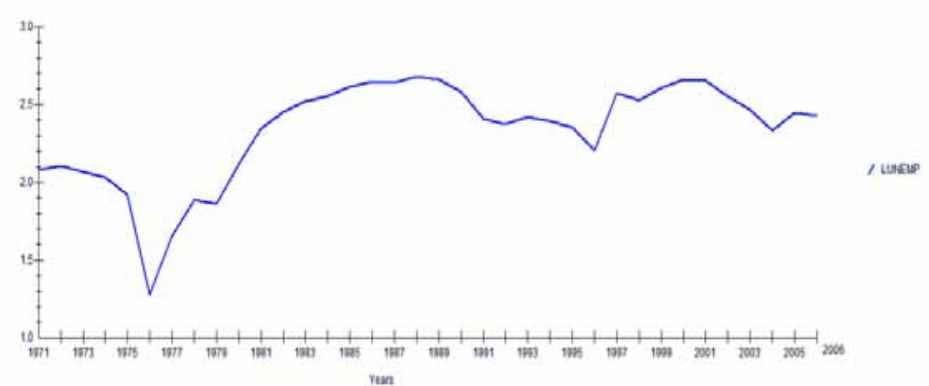

Figure 2. Unemployment Rate Trends in Iran

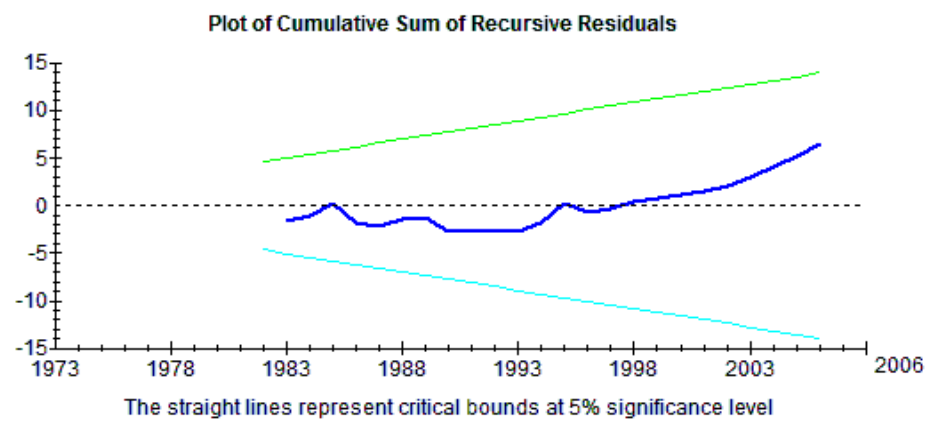

Figure 3. Cumulative Sum of Recurive Residuals

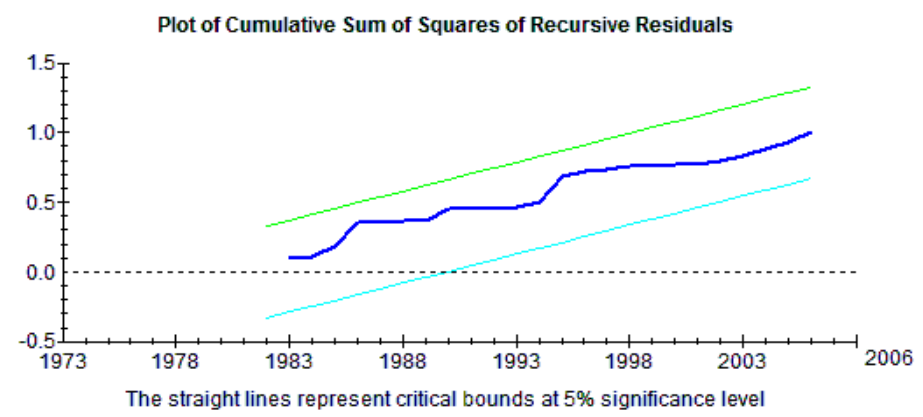

Figure 4. Cumulative Sum of Squares Recurive Residuals 